\title{
Fuzzy model to predict feed intake of Japanese quails
}

Jaqueline de Oliveira Castro - Tadayuki Yanagi Junior •

Leonardo Schiassi - Edison José Fassani - Patrícia Ferreira Ponciano Ferraz

JO Castro (Corresponding author) - T Yanagi Junior • L

Schiassi - PFP Ferraz

Department of Engineering, Universidade Federal de Lavras (UFLA), Lavras, MG, Brazil.

email: jaqueline.castro@deg.ufla.br

\section{EJ Fassani}

Department of Animal Science Universidade Federal de Lavras (UFLA), Lavras, MG, Brazil.

Received: May 23, 2018 - Revised: August 02, 2018 - Accepted: August 02, 2018

\begin{abstract}
Thermal environment management have been a barrier to increase quail production, once it exerts direct and indirect effects on egg production and welfare. The objective of this study was to develop a fuzzy model to predict feed intake of Japanese laying quails. The model was developed based on data derived from field measurements, laboratory and the literature, regarding the environmental influence on feed intake (FI, g) of Japanese quail in laying. Air temperature $\left({ }^{\circ} \mathrm{C}\right)$ and relative humidity $(\%)$ were defined as input variable, and FI as output variable. Mandani's inference and center of gravity deuzzification methods were used for developing the model, as well as, trapezoidal membership functions for the input and output variables. The standard deviation (SD) among the values of observed and predicted FI by the fuzzy model, ranged from $0.01 \mathrm{~g}$ to $1.10 \mathrm{~g}$, and the average deviation was $0.41 \mathrm{~g}$. The average error (AE) and coefficient of determination $\left(\mathrm{R}^{2}\right)$ found were $2.22 \%$ and 0.93 , respectively. Therefore, the low values of $\mathrm{SD}, \mathrm{AE}$ and high values $\mathrm{R}^{2}$ indicate that the fuzzy model can be applied to estimate feed intake of Japanese quails.
\end{abstract}

Keywords: Coturnix Coturnix Japonica, fuzzy set theory, productive performance, thermal environment

\section{Introduction}

The increase of quail production has found barriers that hinder the exploration and maximization of production (Teixeira et al 2013), one of them is the breeding environment, which have direct and indirect effects on production and animal welfare (Rocha et al 2010). Thus, it is primordial to monitor and to control efficiently the environment variables for the success of production (Silva et al 2013).

High temperatures have been a major problem in poultry. It is known that heat stress leads to many losses because it reduces feed intake and bird performance (Fukayama et al 2005). In thermoneutral zone, however, the birds spend little energy to keep your homeothermy, so that practically all energy assimilated from the diet is designed to productive processes (Araújo et al 2007), because it is related to an ideal thermal environment in which birds found adequate conditions to express their best productive characteristics (Nazareno et al 2009).

Production parameters, such as feed intake, and egg quality are examples of some measures adopted to determine the effects of the thermal environment on bird's performance and welfare (Alves et al 2007). It happens because birds change feed intake is regulated by the energy of the diet and by the nutritional requirement (Moura et al 2010), as well as the ambient temperature (Silva et al 2012). The welfare status changes because in the attempt to maintain their body temperature within the homeostatic limits, the birds reduce feed intake when the environmental temperature increases (Rutz 1994). This decrease in the birds' appetite can be considered as one of the main signs of thermal stress (Hurwitz et al 1980), and thermal stress is an antagonist of welfare (Broom 2011).

For better assess the environment of animal production, innovative methods, such as noninvasive assessment tools and welfare control in confined environment have been adopted (Borges et al 2010). Thus, computational modeling has proven important in decision making for problems difficult to solve in poultry.

The fuzzy set theory, introduced by Lofti A. Zadeh in 1965, objective approach the precision of classical mathematics to the imprecision of the real world, confronting deterministic models to more flexible models, these models involving uncertainty and subjectivity (Melo and Castanho 2008).

The fuzzy set theory shown as a methodology that allows to estimate the performance and animal welfare, since according Ponciano et al (2011), is a mathematical theory applied to the diffuse concepts, which uses linguistic variables, words or sentences based on, which play important role in the treatment of imprecision.

Fuzzy logic supports approximate reasoning rather than exact, whose values are words or sentences in natural or artificial language which play an important role in the treatment of imprecision. There is a pertinence interval in 
which the transition is gradual (it can assume any value between 0 and 1), unlike the classical sets in which the pertinence has bivalent aspect ( 0 or 1 ). The idea is not to model the processes themselves, but rather the actions from expert knowledge, which makes the model versatile, because it brings the possibility of modeling and handling imprecise information, naturally used in human language.

Therefore, fuzzy set theory is an interesting methodology in decision making, enabling the prediction of response variables of interest, such as feed intake, weight gain, feed conversion, body temperature, etc. Therefore, the goal of this study was to develop a model based on fuzzy set theory for predicting feed intake of Japanese laying quail.

\section{Materials and Methods}

A fuzzy model is composed of input and output variables. For each variable, are assigned fuzzy sets that characterize them, and, for each fuzzy set is created a membership function. This function is a numerical, graphical or tabulated function that assigns fuzzy relevance values to discrete values of a variable in its discourse universe, that is the numerical range of all possible real values that a specific variable can assume (Ganga et al 2011).

The proposed fuzzy model was developed based on experimental data derived from a research quail facility, an acclimatized wind tunnel placed in a laboratory for animalthermal environment studies and the literature. The measurements in the research quail facility were from February to May 2010 and from April to June 2011. Data from the acclimatized wind tunnel were obtained during May and July 2012. Literature data related to the influence of the environment (air temperature and relative humidity) on the feed intake (FI, g bird ${ }^{-1}$ day $^{-1}$ ) of Japanese laying quail were derived from several field researches (Sahin and Kucuk, 2003, Araújo et al 2007; Lima et al 2012). The use of control treatments (without any type of treatment that differs of the conventional management) for literature and field data permitted the equivalence with the laboratory data.

The input variables of the proposed model were air temperature $\left(\mathrm{t}_{\text {air }},{ }^{\circ} \mathrm{C}\right)$ and relative humidity $(\mathrm{RH}, \%)$. These variables were chosen once $t_{\text {air }}$ is considered the main meteorological variable that influences the physical environment of the animal (McDowell 1974) and RH have a remarkable influence the thermal balance in environments wherein the heat dissipation by evaporation is crucial to homeothermy (Young 1988).

The fuzzy model predicts the FI of Japanese quail as a function of the input variables, allowing the environment classification. The temperature and relative humidity ranges were chosen because they encompass values that characterize conditions of comfort and stress.

Trapezoidal membership functions were used to represent the input variables $\left(\mathrm{t}_{\text {air }},{ }^{\circ} \mathrm{C}\right.$; $\mathrm{RH}, \%$ ) (Table 1 and Figure 1), because they characterize a data set with similar responses (pertinence degree of 1). This type of profile, with a plateau, is common to depict $t_{a i r}$ and $\mathrm{RH}$.

The ranges proposed for $t_{a i r}$ and $\mathrm{RH}$ were defined with aid of tree specialists. These specialists were selected in accordance with the selection methodology of fuzzy specialists proposed by Cornelissen et al (2002).

Table 1 Fuzzy sets for the input variables, air temperature $\left(\mathrm{t}_{\text {air }}\right)$ and relative humidity $(\mathrm{RH})$.

\begin{tabular}{|c|c|}
\hline Input variables & Fuzzy sets \\
\hline \multirow{6}{*}{ Air Temperature $\left(\mathrm{t}_{\mathrm{air}},{ }^{\circ} \mathrm{C}\right)$} & tair $1[18.0 ; 20.0]$ \\
\hline & $\mathrm{t}_{\text {air }} 2[19.0 ; 22.0]$ \\
\hline & $\mathrm{t}_{\text {air }} 3[21.0 ; 24.0]$ \\
\hline & tair $4[23.0 ; 26.0]$ \\
\hline & $\mathrm{t}_{\text {air }} 5[25.0 ; 30.0]$ \\
\hline & $\mathrm{t}_{\text {air }} 6[29.0 ; 32.0]$ \\
\hline \multirow{5}{*}{ Relative Humidity (RH, \%) } & RH1 $[45.0 ; 55.0]$ \\
\hline & $\mathrm{RH} 2[50.0 ; 65.0]$ \\
\hline & RH3 $[60.0 ; 71.0]$ \\
\hline & RH4 [70.0; 77.0] \\
\hline & RH5 $[73.0 ; 80.0]$ \\
\hline
\end{tabular}


a.

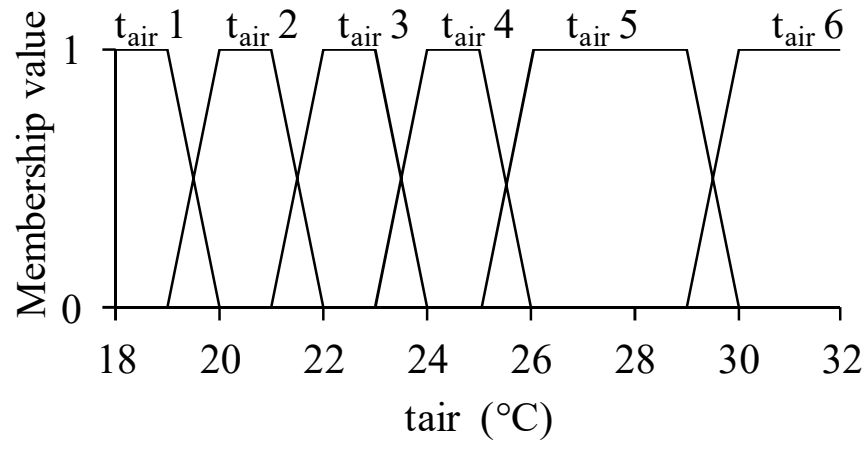

b.

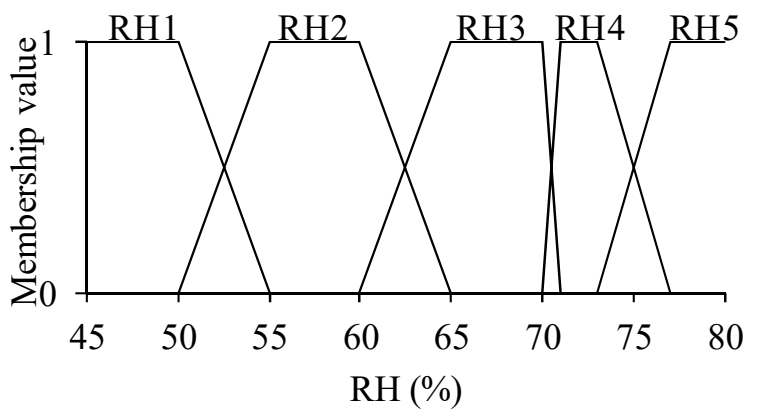

Figure 1 Membership functions for the input variables (a) temperature $\left(\mathrm{t}_{\text {air }},{ }^{\circ} \mathrm{C}\right)$ and $(\mathrm{b})$ relative humidity $(\mathrm{RH}, \%)$ of the air.

The fuzzy inference method used was Mamdani that, in response, brings a fuzzy set originated from the combination of input values with their respective membership value through the minimum operator and then by the superposition rules by the maximum operator (Campos et al 2013). The defuzzification was performed using the method of Center of Gravity (Centroid or Center Area) used by Leite et al (2010).
Trapezoidal membership functions were adopted for the output variable FI (Table 2), because they represent better dataset and result in lower values of standard deviation (Figure 2). The ranges of each membership function were defined by the experts during the development model phase.

The combination of all six membership functions of air temperature $\left(t_{\text {air }}\right)$ and five of air relative humidity $(\mathrm{RH})$ resulted in thirty different thermal conditions, from which it was constructed based on rules.

Table 2 Range of fuzzy sets for the output variable feed intake (FI, g bird ${ }^{-1}$ day $\left.^{-1}\right)$.

\begin{tabular}{cc} 
Output variable & Fuzzy sets \\
\hline & FI1 $[19.0 ; 22.9]$ \\
\cline { 2 - 2 } Feed intake $\left(\right.$ FI, g bird $^{-1}$ day $\left.^{-1}\right)$ & FI2 $[22.0 ; 24.0]$ \\
\cline { 2 - 2 } & FI3 [23.5;25.5] \\
\cline { 2 - 2 } & FI4 [24.9; 26.5] \\
\cline { 2 - 2 } & FI5 [26.0;29.0] \\
\hline
\end{tabular}

The rule set was developed by a collection of fuzzy propositions and with help of specialists (selected by Cornelissen et al (2002) methodology), presented as if-andthen, having been prepared from the information in Table 1 .

The rule system was composed for thirty rules, with a weighting factor equal to 1 was assigned to each rule, similar to several fuzzy models previously adjusted (Ferreira et al
2007; Schiassi et al 2015; Cecchin et al 2016; Tavares and Schiassi 2016).

To evaluate the reliability of the developed model the standard deviation, mean bias error (MBE), percent error and coefficient of determination $\left(\mathrm{R}^{2}\right)$ among the FI values obtained by the fuzzy model and the experimental data were calculated. 


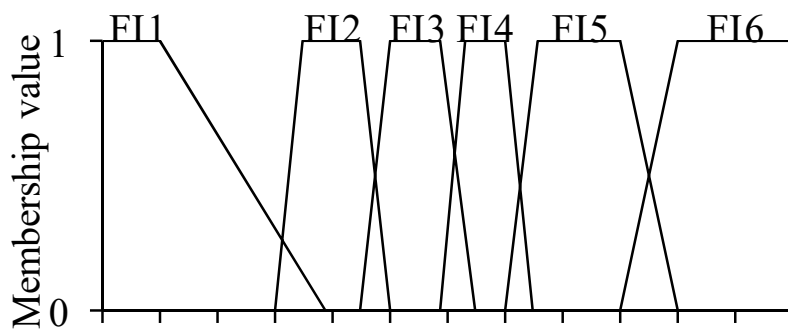

$\begin{array}{lllllllllllll}19 & 20 & 21 & 22 & 23 & 24 & 25 & 26 & 27 & 28 & 29 & 30 & 31\end{array}$

FI (g)

Figure 2 Membership functions to the output variable, feed intake (FI).

\section{Results}

The response surface shown in Figure 3 represents the profile of FI as a function of $t_{\text {air }}$ and $\mathrm{RH}$.

The peaks in Figure 3 indicate the strip of $t_{\text {air }}$ and $\mathrm{RH}$ where the FI is higher, and reciprocally the depressions indicate the environmental strips where verified lower values of FI. It is also possible to observe that the lowest values of FI occur for values of $t_{\text {air }}$ higher than $26^{\circ} \mathrm{C}$.

When a new computer model is developed in order to support the decisions, reviews and tests become important for increasing of system reliability. The experimental FI values (from a research quail facility and laboratory studies) and those predicted through fuzzy model are listed in Table 3.

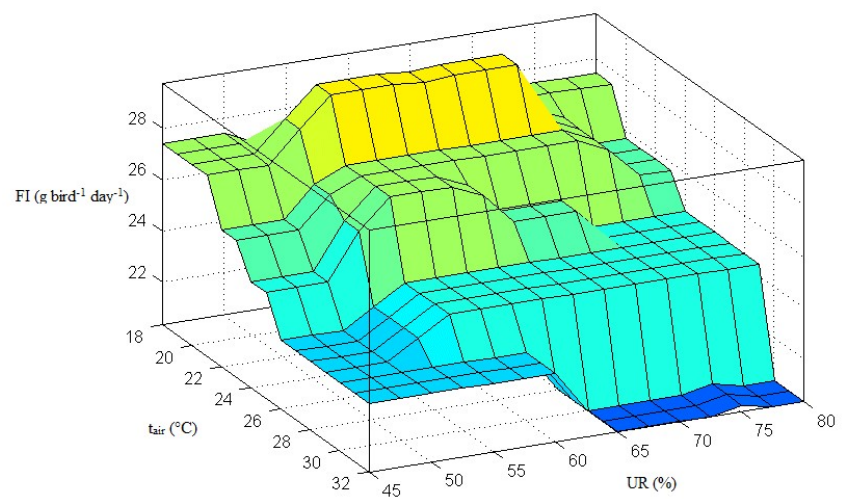

Figure 3 Feed intake (FI) of Japanese quail in function of air temperature $\left(\mathrm{t}_{\text {air }}\right)$ and relative humidity $(\mathrm{RH})$.

The standard deviations among the values of observed and estimated FI by the fuzzy system ranged from $0.07 \mathrm{~g}$ to $0.99 \mathrm{~g}$, with an average deviation equal to $0.41 \mathrm{~g}$. The frequency of occurrence (\%) of the standard deviations was distributed in classes with a range of $0.1 \mathrm{~g}$ to verify whether the percentage of deviations was below of the average value. The distribution of the standard deviations (Figure 4) indicates that $56.6 \%$ of the FI values estimated by the fuzzy system are below of $0.41 \mathrm{~g}$. The MBE, given by the mean of the difference between the simulated and observed data, were 0.17 .

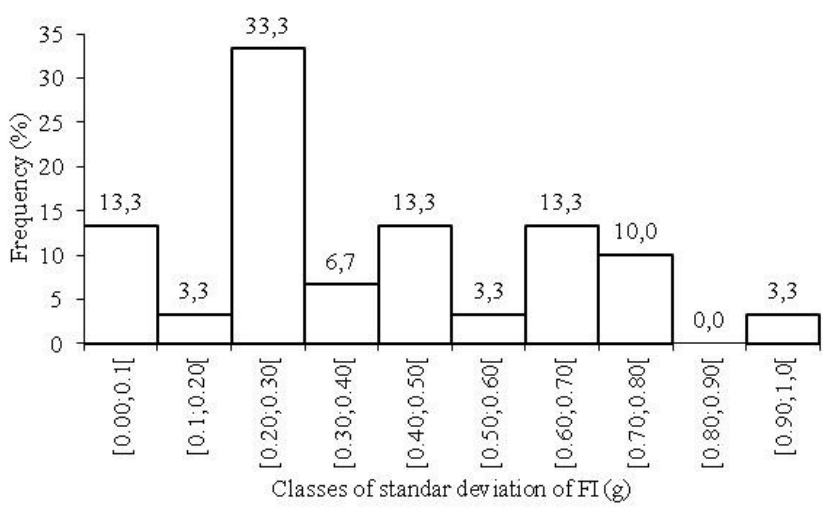

Figure 4 Observed frequencies for the standard deviations between the FI of Japanese quail estimated by the fuzzy model as a function of air temperature $\left(\mathrm{t}_{\text {air }}\right)$ and relative humidity $(\mathrm{RH})$.

The minimum, average and maximum percentage of error found for the fuzzy system were $0.4,2.2$ and $6.1 \%$, respectively, and $55.6 \%$ of the errors are below the average percentage error.

The functional relation among the values observed and simulated FI is illustrated in Figure 5, and the coefficient of determination $\left(\mathrm{R}^{2}\right)$ is equal to 0.93 .

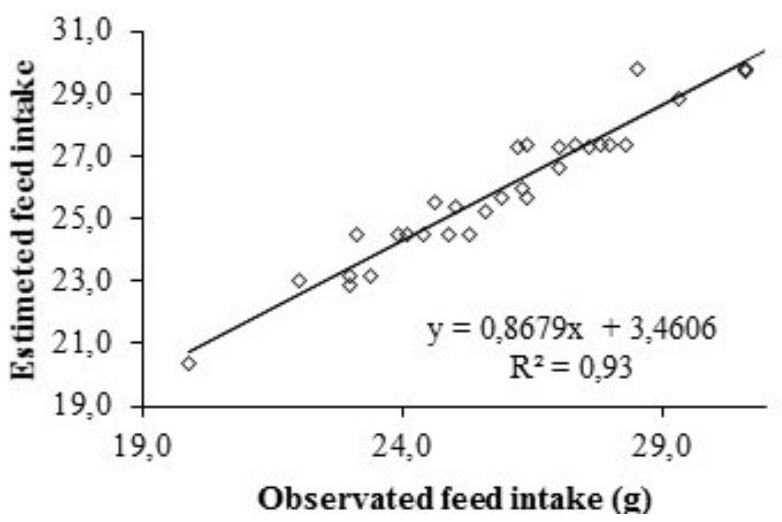

Figure 5 Coefficient of determination $\left(\mathrm{R}^{2}\right)$ generated between the observed feed intake (FI) and estimated feed intake by fuzzy logic. 
Table 3 Comparison among observed and simulated feed intake (FI) values.

\begin{tabular}{|c|c|c|c|c|c|c|}
\hline \multirow[b]{2}{*}{ Source* } & \multirow[b]{2}{*}{$\mathrm{t}_{\text {air }}\left({ }^{\circ} \mathrm{C}\right)$} & \multirow[b]{2}{*}{ RH (\%) } & \multicolumn{4}{|c|}{ Feed intake $\left(\mathrm{g} \mathrm{bird}^{-1}\right.$ day $\left.^{-1}\right)$} \\
\hline & & & Observed* & Fuzzy System & Standard Deviation & $\begin{array}{c}\text { Error } \\
\%\end{array}$ \\
\hline $\mathrm{EF}$ & 19.0 & 56.3 & 25.9 & 25.70 & 0.14 & 0.77 \\
\hline LA & 20.8 & 58.3 & 28.5 & 29.80 & 0.92 & 4.56 \\
\hline LA & 20.8 & 60.1 & 30.6 & 29.80 & 0.57 & 2.61 \\
\hline LA & 21.4 & 60.7 & 29.3 & 28.80 & 0.35 & 1.71 \\
\hline LA & 20.0 & 62.4 & 30.6 & 29.70 & 0.64 & 2.94 \\
\hline Lima et al. (2012) & 21.6 & 75.8 & 27.0 & 26.60 & 0.28 & 1.48 \\
\hline $\mathrm{EF}$ & 22.4 & 42.8 & 26.4 & 25.70 & 0.49 & 2.65 \\
\hline LA & 22.2 & 59.6 & 28.3 & 27.40 & 0.64 & 3.18 \\
\hline LA & 22.2 & 60.3 & 27.3 & 27.40 & 0.07 & 0.37 \\
\hline LA & 22.6 & 65.8 & 27.8 & 27.40 & 0.28 & 1.44 \\
\hline $\mathrm{EF}$ & 22.1 & 69.3 & 26.4 & 27.40 & 0.71 & 3.79 \\
\hline $\mathrm{EF}$ & 23.6 & 71.6 & 26.3 & 26.00 & 0.21 & 1.14 \\
\hline LA & 24.2 & 60.5 & 27.6 & 27.30 & 0.21 & 1.09 \\
\hline LA & 24.2 & 60.5 & 27.0 & 27.30 & 0.21 & 1.11 \\
\hline LA & 24.2 & 60.5 & 26.2 & 27.30 & 0.78 & 4.20 \\
\hline $\mathrm{EF}$ & 24.3 & 70.3 & 25.6 & 25.20 & 0.28 & 1.56 \\
\hline EF & 23.8 & 71.5 & 25.0 & 25.40 & 0.28 & 1.60 \\
\hline $\mathrm{EF}$ & 23.8 & 74.1 & 24.6 & 25.50 & 0.64 & 3.66 \\
\hline LA & 29.9 & 58.7 & 23.4 & 23.20 & 0.14 & 0.85 \\
\hline LA & 28.0 & 59.6 & 23.1 & 24.50 & 0.99 & 6.06 \\
\hline LA & 28.0 & 59.7 & 23.9 & 24.50 & 0.42 & 2.51 \\
\hline LA & 29.9 & 60.0 & 23.0 & 23.20 & 0.14 & 0.87 \\
\hline $\mathrm{EF}$ & 25.7 & 73.9 & 24.4 & 24.50 & 0.07 & 0.41 \\
\hline $\mathrm{EF}$ & 25.9 & 76.7 & 25.3 & 24.50 & 0.57 & 3.16 \\
\hline $\mathrm{EF}$ & 26.0 & 79.5 & 24.9 & 24.50 & 0.28 & 1.61 \\
\hline LA & 31.9 & 60.0 & 22.0 & 23.00 & 0.71 & 4.55 \\
\hline LA & 31.9 & 60.1 & 23.0 & 22.90 & 0.07 & 0.43 \\
\hline Araújo et al. (2007) & 31.8 & 64.9 & 19.9 & 20.40 & 0.35 & 2.51 \\
\hline $\mathrm{EF}$ & 19.0 & 56.3 & 25.9 & 25.70 & 0.14 & 0.77 \\
\hline LA & 20.8 & 58.3 & 28.5 & 29.80 & 0.92 & 4.56 \\
\hline LA & 20.8 & 60.1 & 30.6 & 29.80 & 0.57 & 2.61 \\
\hline LA & 21.4 & 60.7 & 29.3 & 28.80 & 0.35 & 1.71 \\
\hline Lima et al. (2012) & 21.6 & 75.8 & 27.0 & 26.60 & 0.28 & 1.48 \\
\hline $\mathrm{EF}$ & 22.4 & 42.8 & 26.4 & 25.70 & 0.49 & 2.65 \\
\hline Sahin; Kucuk (2003) & 22.0 & 58.0 & 28.0 & 27.40 & 0.42 & 2.14 \\
\hline LA & 22.2 & 59.6 & 28.3 & 27.40 & 0.64 & 3.18 \\
\hline & & & & Average & 0.41 & 2.22 \\
\hline
\end{tabular}

\section{Discussion}

The FI reduction is a direct result of heat stress. In an attempt to maintain their body temperature within homeostatic limits, quails reduce their FI when the ambient temperature increases. As a consequence of the FI reduction the essential nutrients intake also decreases, leading to a reduction in egg production at high temperatures.

When assessing the lighting effect on egg production for Japanese quail, Gewehr et al (2005) found that the increase of $t_{\text {air }}$ promoted decrease in FI. Pinto et al (2003), studying the requirements of methionine and lysine, observed that weekly thermal fluctuations of 14.0 to $30.6^{\circ} \mathrm{C}$ and 23.2 to $30.5{ }^{\circ} \mathrm{C}$, respectively, result in a decrease of FI in laying quails.
Thus, the fuzzy system could be onboard in the climate control systems to provide adequate thermal environment for the quails, optimizing the productive performance.

According to Albino and Barreto (2003) the average FI of Japanese laying quail in production period under comfort conditions is between 23.0 and $26.0 \mathrm{~g} \mathrm{bird}^{-1}$ day $^{-1}$, so the average standard deviation is $1.6 \%$ of the maximum amount cited by the authors.

The MBE indicates the systematic error (underestimation or overestimation), the negative value showed that the model was underestimated. According to Combatt et al (2017), MBE values close to 1.0 express little underestimation of the model with respect to the observed data. 
Ponciano et al (2012) estimate that the FI of broilers through fuzzy sets obtained average percentage error $2.38 \%$ higher than found in this study.

Despite the $\mathrm{R}^{2}$ found to distance from that found by Ponciano et al (2012) ( $\mathrm{R}^{2}$ equal to 0.99 ) was similar to that found by Medeiros et al (2005) that adjusted a mathematical model to estimate FI of adult broiler chickens as a function of air temperature, relative humidity and velocity, founding $\mathrm{R}^{2}$ equal to 0.91 .

The application of fuzzy sets has been shown adequate to various biological models, it allows treating imprecision and uncertainty, such as those found when relating environment and animal performance. The developed system can be easily adapted and changed as new research is conducted, allowing the best fit of the model to the reality of animal production systems. Due to those characteristics, fuzzy models have gained prominence in poultry production, and showed from the model developed also be promising in quail production.

\section{Conclusions}

The fuzzy model developed can be used to estimate the feed intake of laying Japanese quail based on air temperature and relative humidity.

\section{References}

Albino LFT, Barreto SLT (2003) Criação de codornas para produção de ovos e carne. 1 ed. Viçosa: Aprenda Fácil Editora.

Alves SP, Silva IJO, Piedade SMS (2007) Avaliação do bem-estar de aves poedeiras comerciais: efeitos do sistema de criação e do ambiente bioclimático sobre o desempenho das aves e a qualidade de ovos. Revista Brasileira de Zootecnia 36:1388-1394.

Araújo MS, Barreto SLT, Donzele JL, Oliveira RFM, Umigi RT, Oliveira WP, Balbino EM, Assis AP, Maia GVC (2007) Níveis de cromo orgânico na dieta de codornas japonesas mantidas em estresse por calor na fase de postura. Revista Brasileira de Zootecnia 36:584588 .

Borges G, Miranda KOS, Rodrigues VC, Risi N (2010) Uso da geoestatística para avaliar a captação automática dos níveis de pressão sonora em instalações de creche para suínos. Engenharia Agrícola 30:377-385.

Campos AT, Castro JO, Schiassi L, Yanagi Junior T, Pires MFA, Mattioli CC (2013) Prediction of free-stall occupancy rate in dairy cattle barns through fuzzy sets. Engenharia Agrícola 33:1079-1089.

Cecchin D, Campos AT, Schiassi L, Da Cruz VMF, Sousa FA (2016) Índice fuzzy para o conforto térmico de suínos na fase de crescimento e terminação com base na temperatura superficial e frequência respiratória. Energia na Agricultura. doi: http://dx.doi.org/10.17224/EnergAgric.2016v31n4p334-341

Cornelissen AMG, Van Den Berg J, Koops WJ, Kaymak U (2011) Eliciting expert knowledge for fuzzy evaluation of agricultural production systems. Rotterdam: Erasmus Research Institute of Management, 2002. (Report, ERS-2002-108-LIS). http://papers.ssrn.com/sol3/papers.cfm?abstract_id=371055.

Accessed on: 20 dec.
Combat MPM, Mendonça, RCS, Valente, GFS, Silva CM (2017) Validação do processo de eletrocoagulação e avaliação da eletrodissolução de eletrodos no tratamento de efluentes de abatedouros de aves. Química Nova 40:447-453.

Ferreira L, Yanagi Junior T, Nääs IA, Lopes MA (2007) Development of algorithm using fuzzy logic to predict estrus in dairy cows: part I. Agricultural Engineering International: the CIGR Ejournal 9:1-16.

Fukayama EH, Sakomura NK, Neme R, Freitas ER (2005) Efeito da temperatura ambiente e do empenamento sobre o desempenho de frangas leves e semipesadas. Ciência e Agrotecnologia 29:272-1280.

Ganga GMD, Caspinetti LCR, Politano PR (2011) Gestão de desempenho em cadeias de suprimento usando lógica fuzzy. Gestão e Produção 18:755-774.

Gewehr CE, Cotta JTB, Oliveira AIG, Freitas HJ (2005) Efeitos dos programas de iluminação na produção de ovos de codornas (Coturnix coturnix). Ciência e Agrotecnologia 29:857-865.

Leite MS, Fileti AMF, Silva FV (2010) Desenvolvimento e aplicação experimental de controladores fuzzy e convencional em um bioprocesso. Revista Controle \& Automação 21:147-158.

Lima HJD, Barreto SLT, Valeriano MH, Vieira DVG, Costa SL (2012) Densidade inicial de alojamento de codornas japonesas na fase de postura. Global Science and Technology 5:186-193.

McDowell, RE (1974) Bases biológicas de la producción animal em zonas tropicales. 1.ed. Zaragoza: Acribi.

Medeiros CM, Baêta FC, Oliveira RFM, Tinôco IFF, Albino LFT, Cecon (2005) PR Índice térmico ambiental de produtividade para frangos de corte. Revista Brasileira de Engenharia Agrícola e Ambiental 9:660-665.

Melo ER, Castanho MJP (2008) Modelagem fuzzy para diagnóstico diferencial da febre aftosa em bovinos. Revista Eletrônica Lato Sensu $4: 1-10$.

Moura GS, Barreto SLT, Lanna, EAT (2010) Efeito da redução da densidade energética de dietas sobre as características do ovo de codorna japonesa. Revista Brasileira de Zootecnia 39:1266-1271.

Nazareno AC, Pandorfi H, Almeida GLP, Giongo PR, Pedrosa EMR, Guiselini C (2009) Avaliação do conforto térmico e desempenho de frangos de corte sob regime de criação diferenciado. Revista Brasileira de Engenharia Agrícola e Ambiental 13:802-808.

Pinto R, Donzele, JL, Ferreira AS, Albino LFT, Soares RTN, Silva MA, Pereira RA (2003) Exigência de metionina mais cistina para codornas japonesas em postura. Revista Brasileira Zootecnia 32:1166-1173.

Ponciano PF, Lopes MA, Yanagi Junior T, Ferraz GAS (2011) Análise do ambiente para frangos por meio da lógica fuzzy: uma revisão. Archivos de Zootecnia 60:1-13.

Ponciano PF, Yanagi Junior T, Schiassi L, Campos AT, Nascimento JWB (2012) Sistema fuzzy para predição do desempenho produtivo de frangos de corte de 1 a 21 dias de idade. Engenharia Agrícola 32:446-458.

Rocha HP, Furtado DA, Nascimento JWB, Silva JHV (2010) Índices bioclimáticos e produtivos em diferentes galpões avícolas no semiárido paraibano. Revista Brasileira de Engenharia Agrícola e Ambiental 14:1330-1336.

Schiassi L, Yanagi Junior T, Reis GM, Abreu LHP, Campos AT, Castro JO (2015) Modelagem Fuzzy aplicada na avaliação do desempenho de frangos de corte. Revista Brasileira de Engenharia Agrícola e Ambiental 19:140-146. 
Silva EG, Santos AC, Ferreira CLS, Sousa JPL, Rocha JML, Silveira Júnior O (2013) Variabilidade espacial das características ambientais e peso de frangos de corte em galpão de ventilação negativa. Revista Brasileira de Saúde e Produção Animal 14:132-141.

Silva JHV, Jordão Filho J, Costa FGP, Lacerda PB, Vargas DGV, Lima MR (2012) Exigências nutricionais de codornas. Revista Brasileira de Saúde e Produção Animal 13:775-790.

Tavares GF, Schiassi L (2016) Modelagem fuzzy como ferramenta para predição do ganho de peso diário para frangos de corte. Journal of Animal Behaviour and Biometeorology 4:32-38.

Teixeira BB, Euclydes RF, Teixeira RB, Silva LP, Torres RA, SILVA FG, Lehner HG, Caetano GC (2013) Herdabilidade de características de produção e postura em matizes de codornas de corte. Ciência Rural 43:361-365.

Young BA (1988) Effect of environmental stress on nutrient needs. In: Church, D.C. (Ed.) The ruminant animal. New Jersey: Prentice Hall, p.456-467. 